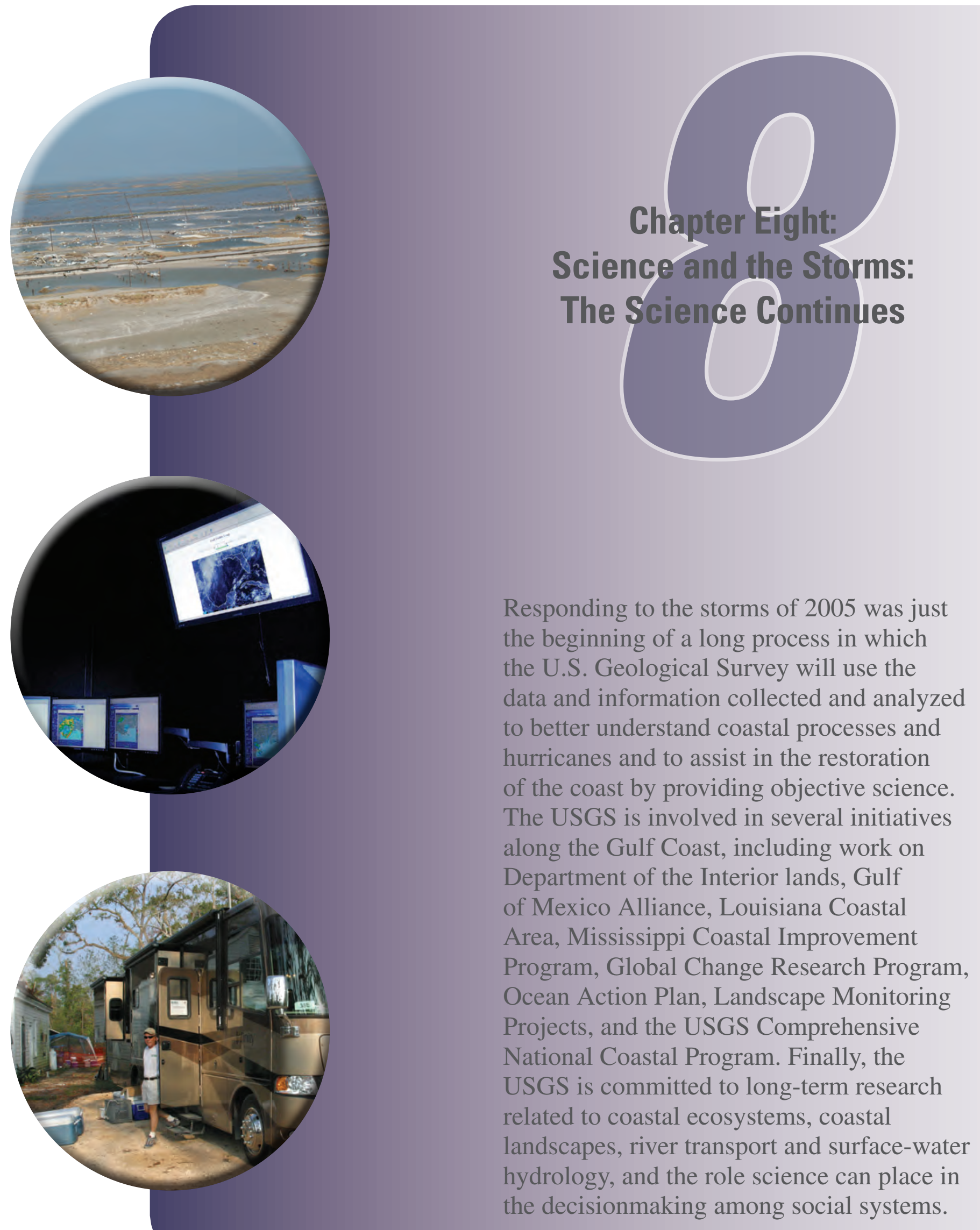




\title{
Current and Future Science Plans for Restoring a Resilient Coast
}

\author{
By Dawn Lavoie
}

The overarching goal of U.S. Geological Survey (USGS)

Gulf Coast science in the aftermath of the 2005 hurricane season will be to provide the scientific information, knowledge, and tools required to ensure that decisions about coastal land resource use, management practices, and future development in the coastal zone and adjacent watersheds promote restoration, increase coastal resilience, and mitigate risks associated with both human-created and natural hazards.

Scientists from all disciplines of the USGS and from science centers throughout the country responded immediately to the hurricanes of 2005. Their activities ranged from life-saving search and rescue missions to gathering perishable data to be used in future studies. The response from the USGS was immediate and effective and served both local and Federal responders well. Many, but not all, of those activities are documented within this circular. The purpose of this epilogue is to place these activities in the context of present and future scientific studies along the northern Gulf of Mexico coast and in relation to the goals of coastal restoration and hurricane

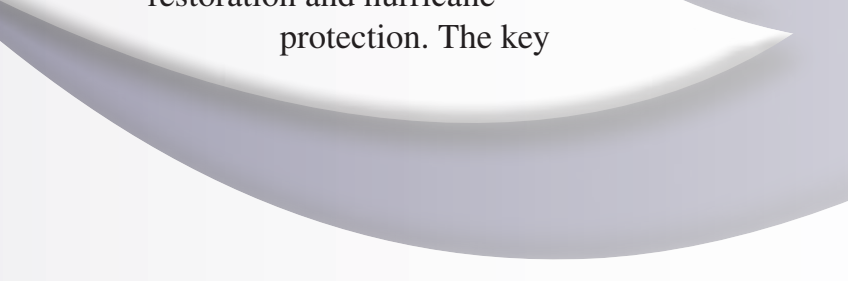

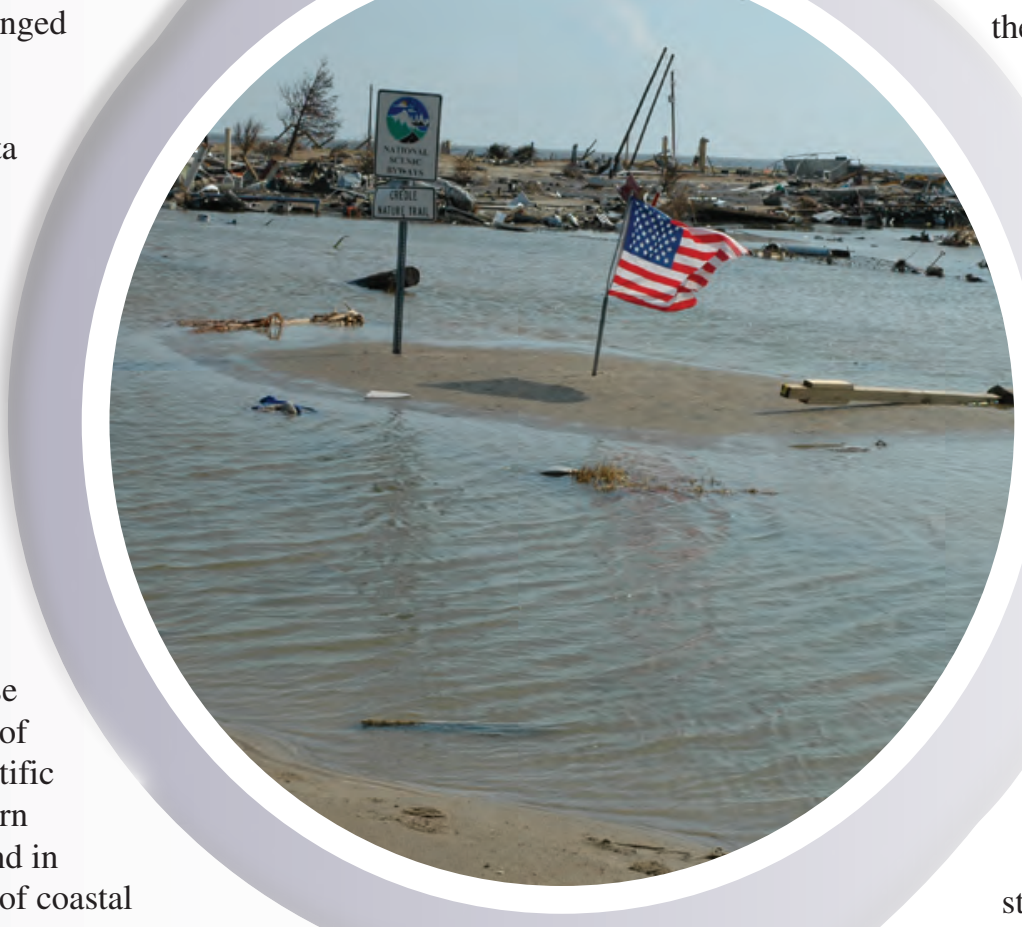

principles

are integration and

coordination of all coastal activities across the USGS.

The future challenge for the USGS is to develop and implement a strategy to provide the science base needed by managers and policymakers.

This science base must be spatially and temporally consistent in order to characterize the variability and vulnerability of the U.S. Gulf Coast. The complexity of the Gulf Coast ecosystems requires an integrated "systemscience" approach aimed at understanding the response of linked elements of coastal systems to multiple stressors and influences. An effective approach must develop information and understanding that address the regional scope of change in the Gulf of Mexico coast.

The answers to the following research questions will provide the information needed to make informed decisions concerning restoration and hazard risk reduction and guide our long-term science plans.

- What are the processes, both natural and human, that affect coastal vulnerability? 
- How will coastal rebuilding and restoration affect coastal resiliency?

- How will future storm protection activities affect the natural resources and the human-built environment of the Gulf Coast?

- How can we use this information to help sustain economic and natural resources and to lessen the effects of future storms?

The increased knowledge resulting from these answers will allow restoration and hazard mitigation to be evaluated with a more complete understanding of their probable effects on coastal ecosystems and communities and will lead us to an assessment of coastal vulnerability to natural and humandriven change.

\section{Why the Northern Gulf of Mexico? It's America's Coastal Heartland!}

The 20th century was a time of gradual realization that the health of our environment was vital to the well-being of our society. During that century, we also began to realize that preserving natural resources had economic and social benefits. The northern Gulf of Mexico coast, where the societal and natural pressures are arguably as complex as anywhere in the world, is one of the best examples of these two realizations. The northern Gulf of Mexico contains some of the world's most diverse and productive ecosystems, including a large percentage of the Nation's estuaries, barrier islands, and salt and fresh marshes. These resources are increasingly threatened not only by population and development pressures but also by the impacts of severe storms such as the series of hurricanes that visited the northern gulf in 2004 and 2005.

Living resources are also under intense pressure from the oil and gas markets; navigation and flood control projects; and large-scale land use associated with industrial, agricultural, and municipal development. The Mississippi River Deltaic Plain is experiencing extreme rates of coastal erosion, subsidence, and land loss. Rising sea level is exacerbating the substantial effects of coastal storms and hurricanes. The growing pressures of coastal development are responsible for many of the current stresses to coastal resources, which include declining water quality, increased sediment pollution, increased flooding, loss of barrier islands and wetlands, and declining fisheries. The Gulf ranks first in the United States for Continental Shelf oil and gas production, and the region processes over 67 percent of the Nation's oil imports (Louisiana Department of Natural Resources, 2006). The impact of catastrophic storms such as Hurricanes Katrina and Rita may have long lasting effects on the Nation's economy, as exemplified by the immediate and sustained rise in gasoline prices.

Numerous other concerns impact this region as well. Invasive and nuisance species are a serious threat to native biota in many Gulf Coast ecosystems and can be transported over large geographical distances by storms. In terms of environment sustaining society, during normal summers about 25 percent of the Gulf Coast's shell-fishing areas are closed because of contamination. Increased nutrient loading of the Mississippi River results in a seasonal hypoxic zone covering about 7,000 $\mathrm{mi}^{2}\left(18,130 \mathrm{~km}^{2}\right)$, and chronic algal blooms occur in many of the region's inshore waters (http:// www.nos.noaa.gov/products/pubs_hypox.html). Over 80 percent of the Nation's coastal wetland losses have occurred in the Gulf Coast region, primarily in Louisiana, since 1940 (Barras and others, 1994, 2003), and predictions of future population growth, coupled with accelerated sea-level rise, suggest increasing pressure on Gulf Coast communities and environments. In spite of this, Gulf Coast ecosystems support most of the Nation's wintering waterfowl and account for about half of the fisheries production in the lower 48 States (http://dnr.louisiana.gov/crm/coastalfacts.asp).

In the summer of 2005, Katrina and Rita impacted the Gulf of Mexico coast from Mobile Bay, Ala., to east Texas, and Hurricanes Dennis and Wilma affected the Florida coast physically, ecologically, socially, and economically. The effects of these storms are still not fully known. Initial USGS observations and past studies of hurricanes in the region suggest that changes will be widespread, persistent, and likely to substantially increase the vulnerability of the region to future storm events. The physical and ecological structure may be altered in ways that pose significant risks to public, environmental, and economic health. For these reasons, the impacts of Katrina and Rita will have effects of national importance.

\section{Importance of USGS Involvement on the Gulf Coast}

Because of its unique charter to provide objective science to our Government at all levels, the USGS is becoming heavily involved in a number of initiatives which will be important to the northern Gulf Coast. The following paragraphs highlight the connection and rationale for a strong USGS presence in the region.

\section{DOI Land Responsibilities}

The USGS, as the primary Federal agency responsible for describing the ecologic, geologic, hydrologic, and geographic structure and resources of the Nation, can provide critical information and research products essential to assess the impacts of Katrina and Rita as well as examine the future vulnerability of coastal communities and resources to coastal change hazards. The U.S. Department of the Interior (DOI) has recommended that DOI bureaus provide an assessment of the damages to natural systems and identify the highest priorities for rebuilding, ecological restoration, and hazard 
reduction. Initial assessments should focus on mapping the extent of loss and identifying priorities for remedial action. The USGS initiated environmental assessment activities immediately in the weeks following the hurricanes and will continue to collect perishable data.

\section{Gulf of Mexico Alliance}

A long-term presence in the northern Gulf of Mexico is enhancing the ability of the USGS to respond to the Governors' Action Plan for Healthy and Resilient Coasts (http://www.dep.state.fl.us/gulf/default.htm). The Alliance is a State-led coalition of State, Federal, and private partners dedicated to addressing a wide suite of issues of concern to Gulf Coast States that will culminate in a healthier Gulf of Mexico ecosystem and economy. As a member of the Alliance, the DOI has made a serious commitment to contribute resources to the five Gulf Coast States. The USGS is contributing science information in the areas of water quality for healthy beaches, wetland and coastal conservation and restoration, environmental education, identification and characterization of gulf habitats, reduction of nutrient inputs to coastal ecosystems, and information management.

\section{Louisiana Coastal Area (LCA)}

The USGS has a long history of working in Louisiana and providing the science to support the activities undertaken by the Louisiana Coastal Area (LCA) Ecosystem Restoration Project. These activities include quantifying rates and causes of subsidence, land loss, and coastal change studies; evaluating wetlands and habitat response to changing environmental conditions; developing geographic information systems; and providing support for data management and workshops. In the wake of Katrina and Rita in 2005, LCA planning by the State of Louisiana has been expanded to include hurricane protection. The USGS, as host to the LCA's Science Board, has an advisory and oversight function for the science and technology that will be undertaken as part of the long-term restoration and hazard mitigation efforts in Louisiana. The science proposed within this plan will complement the various activities being undertaken by the many agencies and researchers involved in the LCA (http://www.lca.gov).

\section{Mississippi Coastal Improvement Program (MsCIP)}

In the aftermath of the 2005 hurricane season, the State of Mississippi is also initiating, with the U.S. Army Corps of Engineers (USACE) and a number of Federal agencies and local stakeholders, a long-term Mississippi Coastal Improvements Program (MsCIP) to determine the nature and level of hurricane protection and environmental restoration required for coastal Mississippi. The driving issues are hurricane protection, flood control, interior drainage, navigation, and ecosystem restoration. Long-term research proposed by the USGS will provide information to help identify and reduce unintended consequences as restoration and hazard mitigation plans evolve and are implemented on the Mississippi Gulf Coast.

\section{Global Change Research Program}

The Global Change Research Act of 1990 established the U.S. Global Change Research Program. As part of this program, the USGS strives to understand the natural and human-induced changes in Earth's global environmental system, to understand and predict global change, and to provide sound scientific information for U.S. decisionmaking. Global climate change and relative sea-level rise on the Gulf Coast exacerbate subsidence and land loss issues. Rates of change are still debated but are absolutely necessary to predict with any certainty whether restoration will succeed. Here again, USGS scientists studying coastal areas of the Northern Gulf of Mexico will contribute to the knowledge base needed for wetlands restoration planning.

\section{Ocean Action Plan}

In 2000, Congress established the U.S. Commission on Ocean Policy. As a result of this commission's recommendations, the President's U.S. Ocean Action Plan established the backbone of a national observing system. The Gulf Coast is the site of the Gulf Coast Ocean Observing System (GCOOS), one of the regional components of the Integrated Ocean Observing System (IOOS). Several of its objectives and those of the USGS are complementary:

- to detect and predict climate variability and consequences,

- to preserve and restore healthy marine ecosystems,

- to ensure human health, and

- to predict and mitigate against coastal hazards.

As members of both IOOS and GCOOS committees, USGS scientists can influence the priorities and directions of the national and regional ocean observing systems.

\section{Landscape Monitoring Projects}

On a much smaller scale, the USGS has instituted a number of landscape monitoring projects, including one for the Lower Mississippi Valley (LMV) designed to assess the landscape response to environmental changes. The conceptual model or framework identifying the agents of change built under this monitoring thrust will be connected to ecological models being built for the northern Gulf Coast by USGS scientists and partners. 


\section{USGS Comprehensive National Coastal Program}

Finally, the USGS Plan for a Comprehensive National Coastal Program, which was written to guide the investments of the Coastal and Marine Program (http://marine.usgs.gov/ coastal-plan.index.html), defines critical regional needs and addresses national issues associated with coastal change, including the following:

- nutrient enrichment,

- habitat change,

- declining living marine populations, and

- increases in susceptibility of coastal communities to natural hazards and sea-level rise.

These needs, already serious when this plan was written, are especially critical in the post-Katrina landscape. The science plan developed for the Gulf Coast, "Northern Gulf of Mexico: USGS Science Contributions to a Resilient Coast," will effectively implement a significant portion of the USGS Coastal and Marine Program.

\section{Long-term Science}

Whereas in the short term the hurricanes of 2005 provided a natural laboratory along the Gulf Coast for the USGS to study the effects of storms on coastal systems, the science that the USGS plans and provides for the region must derive from a long-term, sustainable, and integrated program. The USGS must complete the assessment of baseline data against which change will be measured and must also define the components of a resilient and healthy coastal zone.

Long-term science following the devastating hurricanes of 2005 represents the greatest opportunity for coordinating the massive human community recovery effort with the essential natural landscape restoration. Community planning, urban recovery efforts, and regional-scale coastal planning can be done with or without the benefit and consideration of the natural landscape patterns, coastal processes, and ecological integrity. Urban planning, coastal restoration, and hazard mitigation planning based on sound science understanding, however, will more likely lead to predictable and positive results. Science is one important link between these massive recovery and restoration efforts and offers the tools for intelligent coastal planning. The USGS is the only agency that can provide a systematic, integrated approach to realizing a comprehensive understanding of coastal response to hazards.

The coastal systems on the Gulf Coast that suffered significant effects from the storms of 2005 include (1) coastal ecosystems, habitats, and wildlife species; (2) coastal landscape, including the shoreline, barrier islands, and submerged resources; (3) river transport and surface-water hydrology, including nutrient and contaminant inputs; and
(4) social systems, including the role that science plays in decisionmaking.

Each of these four effects is briefly discussed below. To provide the appropriate science and tools that relate to each system, the USGS plans to accomplish the following:

- Complete a comprehensive assessment of each system.

- Define processes affecting coastal change.

- Monitor/measure rates of change of the critical variables within each system.

- Assess risk to system components.

- Model and predict coastal systems response to future events.

- Produce decision models to guide restoration and hazard mitigation planning.

1. Coastal ecosystems, habitats, and wildlife species

Hurricanes Katrina, Rita, Dennis, and Wilma severely impacted ecological systems and associated biological resources across the Louisiana, Mississippi, Alabama and Florida coastal zone. While the full extent of damage is unknown, past studies of the impacts of severe hurricanes such as Hurricane Camile in 1969 and Hurricane Andrew in 1992 (http://soundwaves.usgs.gov/1999/09/meetings.html; http:// coastal.er.usgs.gov/education/crisis/hurricanes/hurric2.html) suggest that significant change is likely to be widespread and long lasting. These changes have significant potential to impact the functions, goods, and services that coastal ecosystems provide to human communities, including the ability of coastal ecosystems to buffer the coast from physical impacts of future hurricanes and severe storms, making the region potentially more protected from future storm events. To address these issues, the USGS is completing the collection of baseline data begun immediately after the hurricanes of 2005 and continuing into 2006 to document the extent of damage; to monitor change (transitory and permanent) in natural and restored wetland ecosystems and habitat; and to provide the science information that will result in developing the linkages between the physical landscape, storm characteristics, and biological response. The objective of these studies will be to understand the impacts of past storms and predict future impacts on coastal ecosystems.

2. Coastal landscapes, including the shoreline, barrier islands, and submerged resources

The vulnerability of the coastal landscape, including the shoreline, barrier beaches, and submerged resources, depends critically on the response of the physical (geology, geomorphology, and elevation) and human (infrastructure and structures, engineered coastlines, and population centers) geography to storm processes including wind, waves, and inundation. Necessary activities will include data collection by using light detection and ranging (lidar) technology, bathymetric surveying, monitoring, research, and modeling 
and predictive-tool development. The objective will be to assess the extent of change to the physical landscape as a function of the 2005 storms and predict future landscape change as a function of both episodic events and long-term processes.

3. River transport and surface-water hydrology, including nutrient and contaminant inputs

Katrina and Rita have altered Gulf Coast hydrologic systems, leaving extensive areas vulnerable to future flooding from coastal storm surge and rivers and altering the movement of water, sediments, nutrients, and contaminants. Tasks under this system will include deploying a rapid-response network to document future storm surges; characterizing storm effects on sediment and river chemistry; and assessing storm effects on shallow coastal aquifers with the objective of assessing coastal vulnerability and hazards associated with altered surface-water hydrology and river transport. The results of this element of study are intimately related to understanding coastal ecosystems and landscape change. These studies are multidisciplinary and integrated at multiple spatial and temporal scales.

4. Social systems and the role that science plays in decisionmaking

Disaster risk is a function of the hazards of a place and the societal decisions and policies made before, during, and after a catastrophic event. The cost in lives and property during the 2005 hurricane season demonstrates the need to augment natural science expertise with improved understanding of the social and economic vulnerability and risk of coastal communities to extreme storms. Research in this area will focus on combining natural hazards and societal vulnerability information so that decisions on posthurricane recovery and future hurricane mitigation, preparedness, and response can be made effectively in ways that minimize risk. The goal of this work will be to assess the vulnerability of coastal communities, determine the extent of land-cover changes caused by the 2005 hurricanes, and develop tools to inform restoration and hazard mitigation plans on the Gulf Coast.

\section{Conclusion}

The articles in this report include studies and applications of technology initiated by USGS scientists during the immediate months after the hurricanes of 2005. Geospatial technology - the integration of years of geologic, biologic, and hydrologic studies with modern spatial and display technology-literally saved lives in the emergency response to the storms. Measurements of change over the landscape, including ecosystems and water and sediment quality, performed immediately after the storms provide valuable early data that are usually missing when charting the recovery of physical systems. These studies are a firm basis for the longterm research that must be done for the northern Gulf Coast.
The framework for our future research must include integrated plans, studies, and recommendations to the many agencies, governments, and groups involved in the restoration and recovery of America's Gulf of Mexico Coast.

\section{References}

Angelle, S., French, T.M., Delmar, W.J., Jr., and Sprehe, P.R., 2005, America's energy corridor-Louisiana serving the Nation's energy needs: Louisiana Department of Natural Resources, 37 p., http://dnr.louisiana.gov/seclexecdiv/ techasmt/policy/wetlands/AW_AmericasEnergyCorridor_ Revised.pdf, accessed on December 12, 2006.

Barras, J.A., Beville, S., Britsch, D., Hartley, S., Hawes, S., Johnston, J., Kemp, P., Kinler, Q., Martucci, A., Porthouse, J., Reed, D., Roy, K., Sapkota, S., and Suhayda, J., 2003, Historical and projected coastal Louisiana land changes1978-2050: USGS Open-File Report 03-334.

Barras, J.A., Bourgeois, P.E., and Handley, L.R., 1994, Land loss in coastal Louisiana 1956-90: National Biological Survey, National Wetlands Research Center Open-File Report 94-01.

Louisiana Department of Natural Resources, Technology Assessment Division, 2006, Selected Louisiana energy statistics-Louisiana energy topic: Baton Rouge, La., http://dnr.louisiana.gov/sec/execdiv/techasmt/ newsletters/2006-07_topic.pdf

\section{Contact Information}

Dawn Lavoie, Gulf of Mexico Science Coordinator (dlavoie@usgs.gov) U.S. Department of the Interior

U.S. Geological Survey

c/o Big Branch Marsh National Wildlife Refuge

61389 Hwy 434

Lacombe, LA 70445 